Miller, L. L., and Whipple, G. H. (1942) J. exp. Med., 76, 421.

Opie, E. L. (1925) J. Amer. med. Ass., 85, 1533.

Ruge, H. (1932) Derm. Wschr., 94, 278.

Special Article (1943) Lancet, 1, 83.

Special Report, Medical Research Council, London (1922) No. 66.

Willcox, W. (1931) Lancet, 2,'112.

\title{
CHATTERTON'S SYPHILIS
}

Systematic reviews on references to the venereal diseases in the literature have been published by J. D. Rolleston (1942) and by Sir D'Arcy Power (1938) in this Journal. Apart from extensive allusions to syphilis in MacLaurin's De Mortuis, a series of medico-historical essays by a medical man, I can only instance the discussion on gonorrhoea in Ernest Hemmingway's Farewell to Arms, and a bare reference to syphilis in Siegfried Sassoon's poem They, a description of the aftermath of the war of 1914-18. The unwillingness to break a taboo, or in some cases the commonness of infection as suggested in Broch's The Sleep Walkers may explain this paucity of allusions to the venereal diseases. It is possibly a reflection of the present enlightment that more than a casual reference to syphilis is to-day permissible in such works as Neil Bell's Cover His Face (1943).

To most of us Thomas Chatterton, "The Marvellous Boy of Bristol," died on 24th August, 1770, in poverty, a suicide from arsenical poisoning. It is surprising to learn from Bell that Chatterton died from arsenical poisoning in the self treatment of his syphilis.

Born in 1752, Chatterton acquired syphilis early in 1769. He could not afford the Greek Water, sold under patent granted to its inventor by George II, at half-a= guinea a bottle, and bought various cheap quack nostrums the only effect of which was to upset his stomach. After drinking large quantities of the Hot Well Water, which it was claimed had been efficient in many cases, without even temporary relief, Chatterton sought orthodox medical treatment, underwent the ordeal of three weeks' painful and distressing salivation, and by the middle of March his cure was pronounced complete. On 24th April Chatterton, having successfully forced the cancellation of his indentures as a scrivener, departed to pursue his literary career in London.

On 21st July, 1770, he found himself once again in the grip of the foul disease. $\mathrm{He}$ was uncertain whether it was a reinfection or 'a relapse. He would not undergo again the ordeal of salivation. He would follow Paracelsus's treatment -fasting, complete abstinence from strong liquor and the taking of arsenical water. Chatterton ate little but fruit, took the arsenical water in increasing doses, and stayed the severe purging and vomiting with opium stick. Despite heroically increased dosage the malady gained ground. He died on 25th August, 1770, leaving the world potentially much poorer in poetry.

A. E. W. McLACHLAN, M.B., Ch.B., F.R.S.Ed., D.P.H.

\section{Investigation upon jaundice incidence}

The increase in incidence of different forms of jaundice in Great Britain has become of considerable interest to the Ministry of Health at whose request the Medical Research Council, acting in consultation with the War Office, are undertaking a special investigation into the subject. The direction of the enquiry, under the chairmanship of Professor L. J. Witts, is in the hands of a committee of the Council with headquarters at the Department of Pathology, University of Cambridge. The team consists of five whole-time members, namely Dr. F. O. MacCallum (senior bacteriologist), Major C. Wilson, R.A.M.C. (physician), Capt. J. A. R. Miles, R.A.M.C. (clinical pathologist), Dr. A. M. McFarlan (epidemiologist), and Dr. M. R. Pollock (assistant bacteriologist). 